Maurer School of Law: Indiana University

Digital Repository @ Maurer Law

1982

\title{
Guarding the Altar: Physiological Restrictions and the Rise of State Intervention in Matrimony
}

Michael Grossberg

Indiana University-Bloomington, grossber@indiana.edu

Follow this and additional works at: https://www.repository.law.indiana.edu/facpub

Part of the Family Law Commons, and the Legal History Commons

\section{Recommended Citation}

Grossberg, Michael, "Guarding the Altar: Physiological Restrictions and the Rise of State Intervention in Matrimony" (1982). Articles by Maurer Faculty. 2156.

https://www.repository.law.indiana.edu/facpub/2156

This Article is brought to you for free and open access by the Faculty Scholarship at Digital Repository @ Maurer Law. It has been accepted for inclusion in Articles by Maurer Faculty by an authorized administrator of Digital Repository @ Maurer Law. For more information, please contactrvaughan@indiana.edu. 


\title{
Guarding the Altar Physiological Restrictions and the Rise of State Intervention in Matrimony
}

\author{
by Michael GrossberG*
}

Marriage law guarded the entrance to the most vital if most common relationship of nineteenth century America, matrimony. Almost ninety per cent of all men and women passed through its portals. In the 1790s Connecticut Supreme Court Reporter Jesse Root expressed the central assumptions of nuptial law when he declared that the idea that "one man should be joined to one woman in a constant society of cohabiting together, is agreeable to the order of nature, is necessary for the propagation of their offspring, and to render clear and certain the right of succession." ${ }^{1}$ Root offered a lawyerly version of the popular belief that stable marriages performed critical roles in the society by producing healthy children, curbing sexual passions, and protecting private accumulation. Faith in these assumptions never waivered amid the tumult of the century. Yet the law did not remain static or hidebound; on the contrary, it underwent periodic revisions as its authors struggled to insure that matrimony met its responsibilities.

Legal changes occurred in large part because postrevolutionary America witnessed the final demise of an earlier colonial conviction that society was best protected by compelling brides and grooms to submit to community and family matrimonial supervision. In its wake came confusion over how tightly to regulate courtship and wedlock. Major alterations in the middle class conception of the family complicated the issue. The family went through a

* Assistant Professor of History and Lecturer in Law, Case Western Reserve University. I would like to thank various colleagues for their comments on various drafts of this article:Morton Keller, Edward Byers, Judith Taylor, Dirk Hartog, Bertram Wyatt-Brown, Brian Gratton, and the members of the Wellesley College History Seminar. Funding for the research was made possible by Crown Fellowships from Brandeis University.

1. 1 Root xxvvi (Ct. 1789-1793); see also Paul H. Jacobson, American Marriage and Divorce (New York 1951). 
process of redefinition as capitalist enterprise and the republican state gradually took over many of its most important productive and public functions. A more private conception of the family emerged, one in which the household occupied a narrower place within a secular society but whose heightened emotional and affective bonds and socialization duties came to be seen as particularly crucial to social welfare. ${ }^{2}$ The tendency to rely on the private family as the society's primary institution for confronting the vicissitudes of nineteenth century economic and social dynamics greatly exacerbated the problems of legal definition. Out of these developments came a series of policies which tried to guard the nuptial entrance by balancing a doctrinaire faith in individual autonomy with an increasingly insistent demand that the state oversee the vital act of matrimony.

Telling changes in the focus of nuptial law disclose a tension that existed between contractual freedom and state intervention throughout the century, a tension that permeated the entire legal system. As in other areas of the law, state after state shifted the center of attention in nuptials from an initial promotion of private rights to a later imposition of greater public controls. Early in the period marriage law paralleled the larger distributive trend of legal development, including its hostility to unproductive vested interests and undynamic policies. In matrimony, as in many aspects of commerce, legislators and judges, remade the law to compel couples to make their own agreements. Such a free market approach to an issue like matrimony points to a broad early nineteenth century determination to make the law of domestic relations an ally not a competitor in the creation of a society based as much as possible on the bourgeois ideal of unregulated private competition and individual choice. ${ }^{3}$

Events gradually undermined this approach to nuptials. The evangelical and romantic ideals of the family as a refuge, popular in the Jacksonian era, became a Victorian orthodoxy. Deviations from it, such as rising divorces, falling white birth rates, and expanding women's rights, came to be seen as threatening. Family advice writers, clergymen, jurists, and social critics mourned the loss of san-

2. Barbara Laslett, "The Family as a Public and Private Institution: An Historical Perspective," Journal of Marriage and the Family, 35 (1973), 480-92; Kirk Jeffery, "The American Family as a Utopian Retreat from the City," Soundings, 55 (1972), 21-41: John P. Demos, "The American Family in Past Time," American Scholar, 13 (1974), 442-46; Eli Zaretsky, Capitalism, the Family, and Personal Life (New York 1976); Carl Degler, At Odds, Women and the Family in America from the Revolution to the Present (New York 1980), chap. 1.

3. See for example Morton Horwitz, The Transformation of American Law (Cambridge, Ma. 1977), esp. 56-58; William E. Nelson, Americanization of the Common Law (Cambridge, Ma. 1975), esp. chap. 8. 
tified values of the home. Apprehension over the family dominated public discussions of marriage law during the late nineteenth century and into the next. Calls for greater attention to the social impact of loosely governed nuptials testify to growing anxiety about the role of matrimony in maintaining what appeared to be an increasingly unsteady secular and overly permissive social order. Abba Woolson, a prominent eastern feminist, voiced that concern in 1873 when she cautioned: "whatever tends to deteriorate the marriage relationship and consequently the home, tends to deteriorate the whole machinery of life whether social or political." ${ }^{4}$ As in so many areas of conflict in late nineteenth century America, state intervention began to be touted as the solution to these difficulties. Steadily rising public regulation of nuptials emerged as the final response to the central issue of nineteenth century marriage law: defining the boundaries between private nuptial rights and state marital responsibilities. ${ }^{5}$

The evolution of one marital restriction, physiological prohibitions, vividly reveals the ideas and interests which kept altering the balance in nuptial law. The matrimonial curb had four major categories: race, age, kin ties, and mental and physical health ${ }^{6}$ General policies developed over the course of the century and followed in most jurisdictions rather than local or regional anomolies offer the most suggestive evidence of the evolving character of marriage law. From public arenas, such as courtrooms, legislative chambers, and legal and lay journals, came the clearest pronouncements on the physiological traits considered sufficiently threatening to warrant formal prohibition and on the shifting responsibilities of the betrothed and the state.

The development of the nuptial restriction also discloses some sources of legal change generally overlooked in discussions of

4. Women in American Society (Boston 1873); and see Walter E. Willcox, "The Marriage Rate in Michigan, 1870-1890," Publications of the American Statistical Association, 4 (1895), 1-11; Frank G. Cook, "The Marriage Celebration in the United States," Atlantic Monthly, 61 (1888), 527; Ibid., "Reform in the Marriage Celebration," Ibid., 681; "Why is Single Life Becoming More General?" The Nation, 6 (1868), 190-91.

5. For a more thorough examination of these issues see Michael Grossberg, "Law and the Family in Nineteenth Century America," (Unpublished Ph.D. Dissertation, Brandeis University 1979), esp. chaps. 3, 4, 10, 11.

6. The other major physiological restraint, impotence, played a very small role in nineteenth century marriage law. For a discussion of the subject see Devanbaugh v. Devanbaugh, 5 Paige 554 (New York 1836). Traditional English grounds for denying the right to wed provided the foundation for most physiological restrictions. Each prohibition originated in the consensual nature of matrimony and represented a different manner of nullifying a union due to defective consent. For English law see William Blackstone, Commentaries on the Laws of England (London 1765-1769), II: Thomas Poynter, A Concise View of the Doctrines and Practices of the Ecclesiastical Courts (London, 2nd. ed., 1825), esp. chaps. 1-6. 
nineteenth century American legal history. The major interpretive modeis used to analyze the period, such as J. Willard Hurst's progression from 'release of energy' to 'control of the environment' or Morton Horwitz's shift from 'instrumentalism' to 'formalism', have been almost exclusively, and often narrowly, economic. They have encouraged a rather rigid deterministic set of arguments which exclude social and cultural influences on legal development. In other words, legal history has developed its own version of the 'reasonable man' and like the original fiction he (and much less often she) is generally a one-dimensional economic actor who is embroiled in controversies involving 'hard' not 'soft' law. A look at the physiological restraints on matrimony can help correct this historical oversight by enlarging the roster of causal elements at work within the nineteenth century legal system. It can do so in particular by identifying some of the social and cultural forces which produced the impulse to look to state intervention as the solution to the problems of an increasingly expansive, diverse, and class conscious society. The impulse has been explained almost uniformly in economic terms, but the sources of state intervention. ran much deeper within nineteenth century America than such explanations suggest. ${ }^{7}$

\section{Racial Barriers}

Alterations in racial prohibitions within nuptial law provide telling examples of changes in nineteenth century legal policies. The ban on interracial marriage made a dramatic transition from a major anomoly in American marriage law to a representative model for the imposition of physiological restrictions on brides and grooms. Unlike most of the curbs, the racial bar was an American innovation without English precedent. First imposed by several colonial assemblies, it became a regional phenomenon after the Revolution. The most racially conscious states formally banned such unions, the rest made the more common antebellum assumption that private prejudice would accomplish the same result. ${ }^{8}$

The use of public authority to regulate interracial unions made the ban exceptional. In most situations the early nineteenth century

7. James Willard Hurst, Law and the Conditions of Freedom in the Nineteenth Century United States (Madison, Wis. 1956); Ibid., Law and Social Process in United States History (New York 1972), esp. 8-9; Horwitz, The Transformation of American Law; Lawrence E. Friedman, Contract Law in America (Madison, Wis. 1965); for an exception to the general trend see Morton Keller, Affairs of State, Public Life in Late Nineteenth Century America (Cambridge, Ma. 1977), esp. chaps. 12, 13.

8. Jonathan Alpert, "The Origins of Slavery in the United States, The Maryland Precedent," American Journal of Legal History, 14 (1970), 189, 109-11; Harvey Applebaum, "Miscegenation Statutes: A Constitutional and Social Problem," Georgetown Law Journal, 53 (1964), 49-50. 
statutory and common law of marriage encouraged the decline of strict state controls as well as of kin and religious supervision of nuptials. Marriage law championed freedom of choice. Common law marriage, unions consummated without formal ceremonies or public involvement, stood as the most extreme symbol of a commitment to what might be labeled a free marriage market. State judges like Chancellor James Kent of New York made the most important contributions to this legal policy by formally loosening the already declining colonial nuptial laws, which had demanded banns, licenses, parental consent, and other public acts for legally valid marriages. In the place of public supervision, the law endorsed self-policing as the primary check on brides and grooms. ${ }^{9}$

As in so many areas of antebellum life, though, race ran like a fault line through marriage law. The formal ban on interracial unions had a dubious legal standing because it lacked an English pedigree. Its legal bastardy was evident in the first systematic presentation of American marriage law, Joel P. Bishop's 1852 Commentaries on the Law of Marriage and Divorce ${ }^{10}$ One of the earliest comprehensive American legal treatises, Bishop sought to impose order on the maze of statutory and judge-made law governing wedlock. The book was as well an aspect of the larger campaign by mid-century treatise writers to rationalize the diffuse legal culture of America and to protect the policy-making prerogatives of the bench and bar by creating a national common law. Such an endeavor seemed so necessary and rewarding that Bishop gave up a successful practice to pursue a full-time career of legal investigation and writing. ${ }^{11}$

An active opponent of slavery, Bishop nonetheless made a particularly revealing attempt to make room for the racial curb in the common law tradition. He cited with approval an 1841 Kentucky

9. For examples of such judicial actions see Fenton v. Reed, 4 Johns. 51 (N. Y. 1809); Hantz v. Sealy, 6 Binn. 405 (Pa. 1814); Londonderry v. Chester, 2 N.H. 268 (1820); Patton v. Philadelphia, 1 La. An. 98 (1846); Graham v. Bennett, 2 Cal. 503 (1852); Hargrove v. Thompson, 31 Miss. 211 (1856). For discussions of colonial family policies see John Demos, A Little Commonwealth, Family Life in Plymouth Colony (New York 1970); Edmund Morgan, The Puritan Family (Boston 1944); Maxwell Bloomfield, American Lawyers in a Changing Society (Cambridge, Ma. 1976), 91-110; Lorena Walsh, "Till Death Do Us Part, Marriage and Family in Seventeenth Century Maryland," in Thad W. Tate and David L. Ammerman, The Chesapeake in the Seventeenth Century: Essays on Anglo-American Society and Politics (New York 1979), 129-52. For explanations of this regulatory reluctance see James Willard Hurst, The Growth of American Law (Boston 1950), 48; William E. Nelson, "Officeholding and Power Wielding: An Analysis of the Relationship Between Structure and Style in American Administrative History," Law and Society Review, 10 (1976), 191-219.

10. Commentaries on the Law of Marriage and Divorce (Boston 1852).

11. Morton Horwitz, "Treatise Literature," Law Library Journal, 69 (1976), 46061. 
decision which rejected property claims based on the marriage of a white woman and a black man. The justices had ruled that because no formal proof of the union had been presented they had to assume that such interracial relations had been "concubinage" rather than matrimonial. ${ }^{12}$ Bishop endorsed the reasoning by comparing the decision with an English opinion nullifying an alleged marriage between a countess and her footman. An English tribunal had accepted the aristocrat's contention that disparity of rank substantiated her claim that she "had chosen to indulge in licentious passion rather. than degrade herself from her high station by espousing her menial servant." ${ }^{13}$ Bishop's easy equation of American racial antipathies to English class prejudices illustrated not only the unceasing determination of American lawyers to find English roots for all legal doctrines, but more importantly the obvious correlation between class and race implicit in the racial prohibition.

Yet such legal sophistry merely emphasized that the regulatory power of the state provided the only secure authority for the ban. The firm commitment of state court judges to common law nuptial rights made it impossible to impose the restriction without legislative initiative. Bridling at its powerlessness to annul the inheritance rights of the children of a marriage between an emancipated black woman and a white man without a statutory ban, the South Carolina Supreme Court reluctantly agreed with the conclusion of a lawyer in an 1842 property dispute: "although such marriages are revolting, and justly regarded as offensive to public decency, they are not contrary to existing law." 14 The willingness of most southern and a few northern legislatures to supply such statutes testifies to the powerful fears evoked by racial intermarriage, fears potent enough to prod state intervention in a generally anti-statist society.

When such statutes existed they won judicial endorsement. A dramatic turnabout by one of the eminent jurists of the Old South documents the intense pressures on the bench exerted by fears of race 'amalgamation' that threatened, in southern terms, social order and family legitimacy. North Carolina Chief Justice Thomas Ruffin faced two appeals in 1832 in which Caucasian grooms sought to annul their marriages with white women by charging nuptial fraud. The men claimed that their mates, with whom they had shared intimate premarital relations, had given birth to mulatto children and thus had falsely held themselves out as fit marital partners.

In the first decision, Ruffin invoked the standard common law rule on the issue and refused to annul Marville Scoggin's marriage.

12. Armstrong v. Hodges, 2 B. Monroe 69.

13. Forbes v. Countess of Strathmore. Ferg. Cons. Law Rep. 113; Bishop, Marriage and Divorce (2nd. ed. 1856), 74-75, and see 183.

14. Bowers v. Newmann, 2 McMill. 472, 381. 
The law insisted that courting couples themselves scrutinize each other and then take the consequences of their thoroughness. Caveat emptor governed marital contracts as it did other bargains. Ruffin told Scoggins, "[t]here is in general no safe rule but this: that persons who marry take each other as they are." ${ }^{15}$ But community sanctions about race-mixing forced the Chief Justice to change his position. In the second opinion, Ruffin publicly acknowledged the popular and professional opposition his first ruling had stirred. As a popularly elected judge and a former speaker of the state assembly, he clearly was politically sensitive enough to know when to bow to popular will. Though he admitted that his reading of the appeal brought by Jesse Barden against his wife Ann would have led him to issue the same verdict as in the Scoggins case, he modified the rule of fraud and dissolved the marriage. Ruffin concluded his opinion with the frank declaration: "This is a concession to the deep-rooted and virtuous prejudices of the community on the subject." ${ }^{16}$ The judiciary's almost total approval of the racial ban at the same time it jealously guarded most nuptial rights exposes the singular ability of community values, in this case, racist notions, to alter the early nineteenth century bench's larger commitment to a free marriage market.

The legitimacy of this solution to interracial marriage came into question when the fall of the Confederacy and the emancipation of the slaves led to a crisis in marriage law. The enlarged legal personality of blacks created by Reconstruction civil rights legislation and constitutional amendments threatened to undermine the prewar foundation for racial distinctions in matrimony. A resurgence of anxiety over racial purity and the determination of whites to retain class and sexual hegemony over their former bondspersons undercut the few radical attempts at nuptial equality. Instead, as the everpresent phobia of interracial sexuality intensified, demands for renewed state intervention multiplied. Legislatures in the south and a few mid-western states responded by reenacting antebellum statutes or passing new prohibitory legislation. In effect, these statutes placed severe limits on the meaning of the Fourteenth Amendment and other Union measures regarding race. ${ }^{17}$

15. Scroggins v. Scroggins, 3 Dev. 535 (N. C. 1832).

16. Barden v. Barden, 3 Dev. 548. See also State v. Hooper, 5 Ire. 201 (N. C. 1844); Commonwealth v. Isaac, 5 Rand. 634 (Va. 1826): Tindall v. Johnson, 5 Mo. 180 (1838); State v. Brady, 9 Hump. 74 (Tenn. 1848).

17. R. Carter Pittman, "The Fourteenth Amendment: Its Intended Effect on Anti-Miscegenation Laws," Virginia Law Review, 42 (1964), 92; Alfred Avins, "Anti-Miscegenation Laws and the Fourteenth Amendment: the Original Intent," Ibid., 43 (1965), 1227; Forrest G. Wood, Black Scare: the Racist Response to Emancipation and Reconstruction (Berkeley, Ca. 1968), 53-79, 143-53; Vernon L. Wharton, The Negro in Mississippi (Chapel Hill, N.C. 1967), 150, 227-29. 
It fell on Reconstruction state courts to integrate the revitalized ban into postwar law. They relied on two major interlocking arguments. First, judges in these cases joined a growing retreat from a full contractual definition of matrimony. This process of redefinition led to the classification of marriage as more of a legal status than a mere contract. Courts and treatise writers like Bishop redefined marriage to lay a foundation for a new balance in nuptial regulations which authorized a larger role for the state.$^{18}$ In litigation involving interracial marriage, judges started to wax eloquent about the uniqueness of matrimony and the inherent right of each state to determine marital capacity. The judiciary's special pleading prevented the new contractual abilities of blacks from undermining racial curbs. It particularly forestalled the classification of marriage as a political rather than a social right under Reconstruction legislation.

The Texas Court of Appeals offered such a defense in 1887. It ruled on Charles Fasher's petition to overturn his conviction for violating the state anti-miscegenation law by marrying a black woman. The judges rejected Frasher's claim that the Fourteenth and Fifteenth Amendments and the Civil-Rights Bill of 1866 made what had come to be called anti-miscegenation laws unconstitutional deprivations of individual rights. Citing Bishop as an authority, they threw over the ban a redesigned cloak of states rights and the noncontractual nature of marriage:

Marriage is not a contract protected by the Constitution of the United States or within the meaning of the Civil Rights Bill. Marriage is more than a contract . . . it is a civil status, left solely by the Federal Constitution and the law to the discretion of the states under their general power to regulate their domestic affairs. ${ }^{19}$

After this dogmatic assertion of the ban's legality, the court did grant Frasher a temporary reprieve from his four year prison term by sending the case back with the demand that definite proof be offered of his wife's race.

In addition to diminishing the contractual aspect of marriage, the judiciary defended the prohibition by arguing that society had to be protected from serious social and physiological effects arising from interracial unions. Only state action could insure private regu-

18. Bishop, Marriage and Divorce, 25-36; Ibid., New Commentaries on Marriage and Divorce (Chicago 1891) I: 181, 34, 35, 25, 420; Ransom H. Tyler, Commentaries on the Law of Infancy (Albany, N. Y. 1882), 806-09; James Schouler, A Treatise on Domestic Relations (Boston 1874), 22-24; Frederick H. Hicks, "Marriage and Divorce in State Constitutions," American Academy of Political and Social Sciences, 26 (1905), 145-58.

19. Frasher v. State, 3 Tex. Ct. of Appeals 263, 276; and see Doc Lomas v. State, 3 Heisk. 287 (Tenn. 1871); State v. Gibson, 36 Ind. 389 (1871). 
larity. Such contentions drew upon a growing body of scientific racial thought and upon pessimistic views of heredity. The Kentucky Supreme Court expressed these convictions in an 1878 case. The justices confirmed the legislative right to regulate interracial matrimony contending that dropping the ban would "legalize intermarriage between the races, deteriorating to the Caucasian blood and destructive of the social and legislative decorum of States." 20 The racial ban thus fell under a growing postwar judicial disposition to enlarge state supervision of health and safety.

In decisions like these the courts fashioned a sturdy new defense of the racial prohibition. Aaron and Julia Green discovered this to their dismay in 1877 when an Alabama Supreme Court composed of Redeemers overturned a ruling by their Republican predecessors who had declared the racial ban unconstitutional. The new bench labeled homes the "nurseries of the States," and wondered who could

estimate the evil of introducing into their most intimate relations, elements so heterogeneous that they must naturally cause discord, shame, disruption of family circles, and estrangements of kindred? While with their interior administration, the State should interfere but little, it is obviously of the highest public concern that it should, by general laws adapted to the state of things around them, guard against disturbances from without.

Julia Green, a Caucasian, spent two years in prison as a violator of the hearth. ${ }^{21}$

Rricial hostility and the political chaos of Reconstruction merged with a growing anxiety about the family evident in the Alabama opinion to preserve and, indeed, expand the right of states to intervene in nuptials and ban interracial marriages. As separation became the chief goal of American race laws, more and more states used the expanded legal defense to add anti-miscegenation statutes to their codes and constitutions. By the end of the century at least twenty-six states and territories prohibited interracial marriages. ${ }^{22}$ These statutory revisions strengthened a consistent determination to use race to limit individual contractual freedom and conversely increase state nuptial authority.

20. Bowlin v. Commonwealth, 2 Bush. 5, 8-9; and see Scott v. State, 39 Ga. 321 (1869); State v. Jackson, 80 Mo. 175, 179 (1883); Jack Greenberg, Race and American Law (New York 1959), 344.

21. Green v. State, 58 Ala. 190, 194, overturning Burns v. State, 48 Ala. 195 (1872).

22. Gilbert T. Stephenson, Race Distinctions in American Law (Boston 1910), 82; Chester Vernier, American Family Law (Stanford, Ca. 1932-1938), I: 204-09; for an attack on an earlier tendency to treat Indians less harshly than blacks see Isaac Franklin, "The Indian Before the Law," Yale Law Reivew, 18 (1908-1909), 331. 


\section{Youthful Limits}

Modifications in the restrictions placed on youthful marriages point out why the racial prohibition ceased to be a legal anomaly. No nineteenth century judge, legislator, or public commentator disputed the use of age as a legitimate basis for nuptial regulation. All agreed that below a certain age children could neither physically consummate a marriage nor intellectually understand its significance. Yet uncertainty lingered over the states' duty to accept marriages formed during the undefined period between childhood and adulthood. It took on legal significance because matrimony customarily acted as a declaration of individual autonomy and independence and raised delicate questions about nuptial rights and state responsibilities. ${ }^{23}$

Early in the nineteenth century most states resolved these uncertainties in favor of a youthful freedom to wed free of public restraints. Legislation and judicial decisions adopted this nonregulatory policy by borrowing traditional English common law age designations. Under the common law, twelve for women and fourteen for men stood as the magical ages at which the law conferred nuptial rights on individuals. Though steeped in feudal ideas of property protection and common sense notions of sexual development, the law on this side of the Atlantic mainly served to protect aberrant antebellum nuptial vows exchanged by couples who wed while being below the average middle class marriage age of the early twenties. ${ }^{24}$

The fate of a few legislative attempts to raise these ages exposes an anti-regulatory bias embedded in this and other non-racial nuptial laws. In an effort to close the gap between expected middle class conduct and the statutes, several legislatures increased the statutory age of marriage. ${ }^{25}$ Yet New York's 1830 legislative attempt to set the minimum marriage ages at fourteen and seventeen was reconsidered and repealed. Critics like Chancellor Kent vigorously challenged the revision as a violation of common law rights ${ }^{26}$ Lucius Chittenden, a Vermont lawyer who edited the second edition of Tapping Reeve's Law of Baron and Femme (the first American volume on family law) argued that such statutes rested on mistaken notions of policy.

23. Joseph F. Kett, Rites of Passage (New York 1977), chap. 1.

24. Henry Swineborn, A Treatise on Spousals or Matrimonial Contracts (London 1686), 18-28, 34, 47-49; Blackstone, Commentaries, I: 436; T. E. James, "The Age of Majority," American Journal of Legal History, 4 (1960), 31-32; Thomas Monahan, The Pattern of Age at Marriage in the United States (Philadelphia 1950), I: 103.

25. Tapping Reeve, The Law of Baron and Femme (New York, 2nd. ed. 1843), 200-201; Ibid., (4th ed. 1862), 313-14.

26. Ibid. 
Though the acts may be "useful to prevent early marriages," he urged that the better policy remained the common law's vindication of individual choices and accountability. By taking that path in Vermont, "a marriage below the age fixed by these statutes is rarely, if ever, met with." 27

Courts rendered other laws ineffective. In 1854 the Massachusetts Supreme Judicial Court eviscerated an 1835 act similar to the aborted New York statute. The justices issued a writ of habeas corpus to the widow Susan Hervey and told her she must release her thirteen year old daughter. The girl had wed Thomas Parton against her mother's wishes. Hervey's plea that the new Mrs. Parton had been deceived did not convince the court, which admonished her:

in regulating the intercourse of the sexes, by giving its highest sanctions to the contract of marriage, and rendering it, as far as possible, inviolable ... and to prevent fraudulent marriages, seductions, and illegitimacy, the common law has fixed that period in life when sexual passions are usually first developed as the one when infants are deemed to be at the age of consent and capable of entering into the contract of marriage.

The judges then ruled that in the absence of a specific command from the General Court declaring premature marriages void, they would treat legislative standards as "directory" not compulsory. Such firm assertions of judicial discretionary power hastened the privatization of marriage law. Judges used that power to render age and other statutory controls such as licenses, witnesses, and registration voluntary. Their opinions cleared the path for common law marriage. ${ }^{28}$

As these examples indicate, initial nineteenth century laws governing nuptial ages replaced an earlier reliance on communal and parental supervision with individual self-determination. They left the regulation of youthful marriage primarily to the dictates of courtship, personal calculations of maturity and economic resources, and the moral and financial arguments of family and community. If inability to support a family, fears of disinheritance, or arguments against hasty weddings did not extinguish the flames of youthful desire then few legal barriers stood in the path of a young couple. A

27. Lucicus E. Chittendon, quoted in Reeve, Baron and Femme (2nd ed.), 200n.

28. Parton v. Hervey, 1 Gray 119, 121; and see Goodwin v. Thompson, 2 Greene 329 (Ia. 1849); Koonce v. Wallace, 7 Jones 194 (N. C. 1859); Bishop Marriage and Divorce (2nd ed.), 162; Governor v. Rector and Ryford, 10 Hump. 57 (N. C. 1849).

29. Pool v. Pratt, I D. Chip. 252 (Vt. 1814); Aymar v. Roff, 3 Johns. Chan. 49 (N. Y. 1817); American Jurist, 20 (1839), 275-76; Arthur Calhoun, A Social History of the American Family (Cleveland 1917), 11: 12, 22, 28-31; Guim Griffis Johnson, "Courtship and Marriage in Antebellum North Carolina," North Carolina Historical Review, 8 (1931), 32. 
free market view of a contract that most Americans assumed would be binding for life reflected a prevalent belief that social and personal influences could more effectively deter undesirable unions than could state intervention. Such assumptions were nourished on the period's definition of liberty which included a strong distrust of governmental interference in community and family life. The age laws also perpetuated the conviction that individuals should be allowed to decide their own fate and then be held to the consequences. ${ }^{29}$ Such a policy added legal support to a more general social evolution described by Daniel Scott Smith. He has identified a gradual movement from the seventeenth and early eighteenth centuries' "stable, parental-run marriage system" to the nineteenth century's "stable, participant-run marriage system." The transition encouraged a reliance not on the state but on internalized restraint and individual conscience in mate selection. The general legal bias in favor of individual decision-making and risk-taking enhanced juvenile nuptial prerogatives by undermining the legitimacy of family and state controls at the same time the law promoted private economic authority. ${ }^{30}$

After the nation passed mid-century, however, these lax nuptial policies came under attack. Critics of nuptial mores from the professions, the press, and new reform organizations like the Social Purity Alliance singled out young brides and grooms as prime sources of marital instability. In 1901 Stanford Professor George E. Howard, a pioneer sociologist, summarized almost fifty years of protest against lax marital age regulation with the query: "majority is the law's simple devise for securing mental maturity in the graver things of life. Is not wedlock as serious a business as making a will or signing a deed?" His question implied both the legal answer and his dissatisfaction with the timidity of nuptial controls on the young. Howard, who became a crusader for numerous progressive causes, called youthful marriages a "fruitful source of evil" and urged legislators to deny them legal recognition. ${ }^{31}$

Like their response to persistent demands for state intervention in commerce which required a devaluation of individual economic rights, many lawmakers reacted to the appeals of reformers like Howard by imposing limits on youthful nuptial rights. A series of acts in the late nineteenth century and early twentieth succeeded in

30. Smith, "Parental Power and Marriage Patterns: An Analysis of Historical Trends in Hingham, Massachusetts," Journal of Marriage and the Family, 35 (1973), 426; see also Calhoun, The American Family, II: 32.

31. Quoted in Fred S. Hall and Mary Brooke, American Marriage Laws (New York 1921), 18; and see W. C. Robinson, "The Diagnostics of Divorce," Journal of Social Science, 14 (1881), 136; Noah Davis, "Marriage and Divorce," North American Review, 139 (1884), 32; David Pivar, The Purity Crusade: Sexual Morality and Social Control, 1868-1900 (Westport, Ct. 1973), esp. 104-05, 139-46. 
raising the average national statutory age of marriage to sixteen for women and eighteen for men. By 1906 the legal trend had become so commonplace that only seventeen states and territories clung to the old common law standard of twelve and fourteen. ${ }^{32}$

These nuptial law revisions occurred amidst a broader reassessment of the social and economic place of the young in American life. Persuaded by educators, physicians, and reformers like Howard, legislators began legally to segregate youths through compulsory school laws, to provide special courts for them with vast discretionary power over status offenses, as well as to limit nuptial freedom. These statutes used the law to protect a Victorian conception of youthful development and marital conduct by prolonging childhood and by saving children from themselves and their misguided parents though the forced imposition of such mores as selfrestraint, educational advancement, delayed-gratification, and domesticity. Howard and other critics of the family firmly believed that these traits held some of the keys to marital bliss and should be imposed by coercive state action. ${ }^{33}$

The new marriage age laws, like many other post-Civil War legislative interventions into what had been considered private matters, received a mixed judicial review. In response to statutory initiatives in economic affairs such as railroad regulation the bench developed a stout defense of what it considered to be common law liberties to contract and use private property..$^{34}$ The new nuptial laws posed similar challenges to the reigning judicial conception of the right to wed. In particular, despite the rising chorus of complaints against youthful marriages, judges and their professional allies retained a greater faith in the social utility of nuptial freedom than did family reformers. As a major legal theorist of the era, Francis Wharton, put it: encouraging early marriage had become "as much a part of the distinctive policy of the United States as to discourage such marriages [was] part of the distinctive policy of Europe." He urged courts to "sustain matrimonial capacity in all cases of persons arrived at puberty. . . ."35

32. Monahan, Pattern of Age at Marriage, II: 333-38.

33. Anthony M. Platt, The Child Savers, the Invention of Delinquency (Chicago 1969); Steven L. Schlossman, Love and the American Delinquent, the Theory and Practice of Progressive Jurisprudence (Chicago 1977); Elen Ryerson, The Best-Laid Plans, America's Juvenile Court Experiment (New York 1978); Keller, Affairs of State, 464-67, 481-82, 483.

34. Keller, Affairs of State, chaps. 5, 8, 9, 11: Clyde Jacobs, Law Writers and the Courts (Berkeley 1954); Robert S. Hunt, Law and Locomotives, The Impact of the Railroad on Wisconsin Law in the Nineteenth Century (Madison, Wis. 1958); Arnold M. Paul, Conservative Crisis and the Rule of Law (Ithaca, N. Y. 1960); William Letwin, Law and Economic Policy in America (Chicago 1966).

35. A Treatise on the Conflicts of Law (Rochester, N. Y. 3rd ed. 1905), I: 332-33. 
Confronting disputes over the scope of the vaguely worded age regulations, judges often had to choose between the settled common law policy of limited state interference and the new legislative restraints put on youthful nuptial rights. In most cases where they could use their discretion, judges chose the common law. The bench treated marriages as voidable when one or both parties wed below the new statutory ages. If the union continued after the spouses had reached these ages, it became permanent. The Supreme Court of Nevada followed this reasoning in finding the 1869 marriage of Jennie C. Dirks valid even though she had wed while three years under the new statutory age of sixteen. The court considered the ceremony before a justice of the peace "a valid binding contract." 36

Judges like those in Nevada obviously did not consider youthful unions as inherently suspect as did critics of family life. In an $\mathbf{1 8 7 6}$ bigamy appeal, the Alabama Supreme Court rejected the contentions of reformers like Howard by favorably comparing violations of the age restrictions to infractions the judges considered much more serious. They swept aside Thomas Beggs' attempt to have his first marriage declared null and void because he had wed when he was below the statutory age of seventeen. The justices concluded that the legislature had not intended to punish such violations as harshly as they did transgressions of other restrictions such as the ban on incestuous unions. They contended that a marriage within the "age of consent may be indiscrete, may disturb the peace of families and may subject youth and inexperience to the acts of the cunning and the unscrupulous, but it is wanting in the vicious and corrupting properties of the incestuous connection which contravenes the voice of nature, degrades the family, and offends decency and morals." 37

Such opinions reflected the persistence within the judiciary of an earlier endorsement of self-regulation and a judicial determination to oversee, and if necessary repel, major legislative invasions of nuptial law. In 1886 Christopher Tiedeman, one of the leading late nineteenth century opponents of what he labeled 'state activism,' endorsed such judicial defenses of common law rights in his highly influential treatise on the limitations of police power. He urged that youth not be made a "disqualification to the entrance into a completely valid marriage." 38 This stance epitomized his belief, as he explained in an 1890 volume, that the notion that "government has

36. Fitzpatrick v. Fitzpatrick, 6 Nev. 63, 67 (1870).

37. Beggs v. State, 55 Ala. 108, 112-13; and see People v. Slack, 15 Mich. 192 (1867); State v. Cone, 86 Wis. 498 (1893); Williams v. Hodges, 101 N. C. 300 (1888); Walls v. State, 32 Ark. 565 (1887).

38. A Treatise on the Limitations of the Police Power in the United States (St. Louis 1886), 531. 
the power to banish evil from the earth" merely represented another reincarnation of an "old superstition." 39

The new age legislation and its judicial reception provide clear illustrations of the emerging character of post-Civil War marriage law. The debate points both to the necessity of turning to the state to alter marriage law and the difficulties of doing so. A new relationship had developed in antebellum America between individual brides and grooms and the state. The traditional hierarchical, patriarchal family of the colonial era no longer existed as a buffer between the two. Instead, the legal identity of each potential spouse had its source in his or her individuality. As the law defined matrimony, an act between two individuals and the state, strengthened nuptial controls would have to come directly from public authorities and not from the family or other intermediaries like the church. But trying to construct a broadly supportable definition of the public interest in nuptials to win the allegiance of all those involved in marriage law proved to be the shoal upon which most attempts broke apart. It was particularly difficult in the case of youthful marriages because they did not engender the intense controversy which had sustained broad state intervention in interracial unions. Yet judges and legislators slowly did establish a new balance between state authority and individual rights which reduced youthful nuptial freedom by raising the formal age of marriage. But it was a balance in which the young and the courts retained large discretionary powers and the state's regulatory authority, though enhanced, was less extensive than in the case of interracial marriage. Though the specific interests and concerns varied in each case, similar revaluations of state power and contractual freedom occurred across the legal spectrum.

\section{Kin Boundaries}

Changes in content and intent similar to those in the racial and age restrictions occurred in another element of the physiological prohibition, the legal standards governing kin ties. Alterations in these regulations had a more direct link than did those in the other two areas to shifting attitudes about nuptial freedom and the state's responsibility to defend matrimony from biological dangers. An initial commitment to contractual rights emerged after the Revolution when state legislatures began to relax the rigid and enclusive statutes governing kin marriages that had been adopted earlier in the colonial era. Truly incestuous marriages - that is, between parent and child or brother and sister-continued to provoke bitter social and legal denunciations. Since such relationships are rarely formalized, the 
central legal and social issue became the boundary of the kin nuptial ban. ${ }^{40}$

Colonial limits had originated in Biblical commands and English canonical rules governing consanguinity and affinity. These family ties, the former created though blood bonds and the latter through matrimony, formed the basis of numerous intricate distinctions, anyone of which could be used to annul a marriage. Cincinnati editor Edward Mansfield, who had graduated from Tapping Reeve's Litchfield Law School and taught law in his adopted city, expressed a popular view on the issue in 1845 when he tried to stake out the proper limits of the kin restriction. Admitting that public welfare demanded some bans on consanguineous unions, he nevertheless asserted that "the holiness or unholiness of the matrimonial contract, in reference to ties of blood or other moral circumstances is not considered by law, but left entirely to the jurisdiction of ecclesiastical bodies or the restraint of conscience." 41

Judgments like Mansfield's sped the gradual liberalization of many kin taboos. His comment indicates some of the social and political sources of that development. In a society which had disestablished religion and enshrined individual rights, most kin nuptials fell outside of what came to be thought of as the proper domain of public authority. Only true incest appeared to pose a serious enough danger to warrant state nuptial intervention. These demarcations may also be a legal recognition of the weakening of kin-bonds during the course of the nineteenth century. ${ }^{42}$

Statutory differences on the issue arose mainly as a result of first cousin and affinal unions. Sociologist Bernard Farber has discovered two nineteenth century kin systems. In New England and much of the older South a 'Biblical System' based on English practice remained in place. It permitted first cousin unions but banned marriages among various affines. At the same time a 'Western American System' emerged in the new states of the middle and far west. Those regions proscribed first cousin unions and authorized affinal ones. The regional divergence is difficult to explain. It may lie in different responses to the problem of social stratification and economic development. The 'Biblical System' helped sustain a highly stratified family oriented social and economic order by pro-

40. Talcott Parsons, "The Incest Taboo in Relation to Social Structure," in Rose Lauber Coser, ed., The Family (New York, 2nd ed. 1974), 13-30; Frederick P. Stokes, "The Incestuous Marriage, A Relic of the Past," University of Colorado Law Review, 36 (1963), 473-74.

41. The Legal Rights, Liabilities, and Duties of Women (Cincinnati, Ohio 1845), 236. For a description of English law see Poynter, Doctrines of Ecclesiastical Courts, 85-118.

42. Degler, At Odds, 104-09. 
viding a formal mechanism for using kin matrimonial alliances to perpetuate concentrated economic power. The 'Western System' promoted a more open society by encouraging marriages with a variety of outsiders and affines and thus expanding the distribution of family wealth. The regional differences thus may reflect the creation of legal policies by and for elites who differed in their use of family alliances to protect or increase their wealth. ${ }^{43}$

In this instance, the West prevailed for the major regulatory development of the early nineteenth century became the gradual reduction of controls on couples related by affinity. A growing number of statutes and judicial decisions dissolved such bonds after the death or divorce of one of the spouses. Massachusetts, Maryland, and Connecticut did so in the late eighteenth century, other states followed their lead in the next. The Vermont Supreme Court agreed as well in an 1837 land dispute. The justices threw out an appeal by Amos Blodgett who had questioned the appraisal of some condemned property because one of the appraisers had married the sister of the owner's deceased first wife. They not only rejected that relationship as a ground of disqualification but the judges also repudiated a traditional common law ban against the unions of widowers and their deceased wife's sisters: "though a man is by affinity, brother to his wife's sister, yet upon the death of the wife, he may lawfully marry his sister." ${ }_{44}^{4}$ This ruling was a rejection of the older Anglo-American policy which had banned such unions as threats to family unity. It proceeded directly from the new assumption that matrimony united two individuals not two families. Consequently, once the original bond ended the remaining spouse could legally wed almost anyone he or she desired. English law did not permit such unions until 1907. Thus, as in nuptial age revision of the same era, individual conscience not the law governed marital choice. ${ }^{45}$

A bitter debate in the Presbyterian Church over this issue revealed the waning influence of public controls on the marriages of individuals formerly related by affinity. Around 1840 the sect defrocked the minister of a Fayetteville, North Carolina congregation, the Reverend McQueen, for marrying his deceased wife's sister. In an ensuing pamphlet war over the action, all the disputants, some albeit grudgingly, conceded the propriety of the legislature's withdrawal from the issue. The disputants quarreled over whether or not

43. Kinship and Class (New York 1971), chap. 3. For a comment on Farber's analysis see Peter D. Hall, "Marital Selection and Business in Massachusetts Merchant Families, 1700-1900," in Michael Gordon, ed., The American Family in Social-Historical Perspective (New York 1973), 101-14.

44. Blodgett v. Brinsmaid, 9 Vt. 27, 30 (1837).

45. George Howard, A History of Matrimonial Institutions (Chicago 1904), 11: 397, 434-35, 474. 
the church itself should enforce the ban. One opponent of the restriction taunted his adversaries: "if the prevailing public sentiment of this nation, sustained by the legislation of all the states but one [most likely he meant Virginia] is countenancing incest, we need to know it." Though McQueen finally won reinstatement in 1846, the debate revealed that traditional nuptial restrictions had to be defended on grounds of public welfare not merely accepted morality. Such standards ensured that few kin marriages fell within the boundaries of the law. ${ }^{46}$

Even in the most litigated issue, marriages between uncles and nieces or aunts and nephews, the courts opposed strict public restraints. In 1858 the South Carolina Supreme Court refused to nullify the marriage of Edward Bowers and his brother's daughter, Elizabeth, in an estate fight. The court rebuffed an attempt by the children of Bower's first marriage to deny Elizabeth dower rights because her marriage violated the ban on incestuous unions. Offering a common judicial argument used to blunt nuptial laws, the justices raised the specter of broken marriages and bastardized children to justify their allegience to the common law. They concluded, "extreme cases of unnatural alliances may be supposed at which the moral senses could be offended, but hithertofore public sentiment if not private virtue has repressed all such evils." Though self-policing had failed to prevent the Bowers' marriage, the South Carolina bench, like most of its antebellum counterparts, refused to rescind its endorsement of that system of nuptial supervision of most kin unions as the judiciary had refused to do in most youthful marriages. ${ }^{47}$

Only an influence as potent as racial prejudice or violations of blood bonds could dislodge the commitment to individual choice embedded in these early nineteenth century kin nuptial policies. The transmission of hereditary defects through marriage began to be considered such a threat around the middle of the nineteenth century. A scientific pessimism first evident in the antebellum defense of the racial ban slowly spread beyond the racial issue and under-

46. Parsons Cooke, The Marriage Question: Or the Lawfulness of Marrying the Sister of a Deceased Wife (Boston 1842); and see Domesticus, The Doctrine of Incest Stated with an Examination of the Question of Whether a Man May Marry His Deceased Wife's Sister (New York 1817); Clericus, The Arguments of Domesticus on the Question of Whether a Man May Marry His Deceased Wife's Sister (New York 1817); Johnson, "Courtship and Marriage in North Carolina," 385-86.

47. Bowers v. Bowers, 10 Rich. Eq. 551, 555 (S. C. 1858); and see State v. Barefoot, 2 Rich. 209 (S. C. 1845); Ward v. Delaney, 23 Miss. 410 (1852); Bonham v. Bagley, 7 Ill. 622 (1845); Sutton v. Warren, 10 Met. 451 (Mass. 1845); Kelley v. Neely, 12 Ark. 657 (1852); Reeve, Baron and Femme, 202-04; Bishop, Marriage and Divorce (2nd ed.), 181-82. Only the gradual elevation of the step-parent/step-child bond to that of natural family members ran counter to this general trend. 
mined the optimism that had been one of the main pillars of liberal nuptial law and its aversion to state intervention. A determination to use marriage law to block the consummation of unions thought to pose hereditary threats became a major product of this shift in outlook.

Alterations in the content and defense of the kin prohibitions offer clues as to the way in which biological fears helped create a scientific rationale for reorienting the law. In each of the numerous editions of his treatise on marriage law, Joel Bishop wrote what he considered to be definitive explanations of the kin restrictions. Yet where the 1852 volume had relied on traditional justifications for the ban, the edition he revised twenty years later used medical arguments to question the very propositions he had so earnestly advanced in the earlier work:

Marriages between persons closely allied in blood are apt to produce an offspring feeble in body, and tending to insanity in mind. They are everywhere prohibited; but the more common reason assigned for the prohibition is, that the toleration of them would impair the quiet of families, jeopardize female chastity, and hinder the formation of favorable alliances. And while this reason appears utterly insufficient of itself, it shows how in the world's history, the promptings of the nature of man frequently carry him in the right direction even where his mere intellect fails to discern the path. ${ }^{48}$

Bishop's revision indicated how fully he had been converted to a biological defense of the incest ban.

Though the relaxation of affinal restrictions, which generated fewer hereditary anxieties, continued unimpeded, the longstanding antipathy to consanguineous unions revived and expanded as biological fears intensified. Heightened interest in the consequences of kin unions eroded support for individual nuptial rights and encouraged public intervention. A legislative attempt to ban those kin marriages which seemed the most threatenting led to greater statutory uniformity around the nation.

By the end of the nineteenth century two significant legislative developments had transpired. First, the number of state laws banning first cousin marriages increased. The passage of these curbs, enacted even though doctors and scientists hotly debated the actual physiological effects of such marriages, suggests a new inclination to take no chances with heredity. That stance, in turn, helps explain the increasingly cautious and often repressive legal environment within which late nineteenth century innovations in marriage law occurred. The acts also record another way in which the 'Western

48. Marriage and Divorce (5th ed. 1873), 273-74. 
System' of kin restrictions achieved legal dominance. Second, states devised more comprehensive nuptial codes which included all possible family members within the incest ban. Fears for the sanctity of the family grew so intense that even adopted children found themselves under statutory supervision. The new laws prohibited marriages between adopted children and their new parents or siblings. In addition, most statutes reversed traditional practice and declared incestuous unions void rather than merely voidable. Some states even authorized criminal penalties for violations of the ban. By 1900 every state prohibited unions of blood relations. Most ended at first cousins, but many went a step further to second cousins. The dramatic rejection of self-policing symbolized by these enactments stood as graphic evidence of the late nineteenth century conclusion that the free marriage market had failed to protect the society from a major biological threat. Only more vigorous state regulation could provide such security. ${ }^{49}$

Rising apprehension about the biological and social effects of incestuous marriages not only weakened popular and professional resistance to state regulation of nuptials it also eroded judicial support for contractual rights. Despite the tightened statutes, most cases coming before the bench continued to be property fights arising from uncle-niece or aunt-nephew marriages. Thus judges generally had to resolve estate disputes and not try to forestall the actual formation what the law now considered socially threatening unions. A survey of such cases indicates that most courts interpreted the acts in such a way as to retain the discretion to use common law rules in applying the more rigorous curbs. Legal authors like Bishop encouraged such interpretations by arguing that the best protection for society lay in judge-dominated rather than legislative directed marriage rules. His advice expressed a widespread determination among the bench and bar to protect the authority over state policymaking delegated to them earlier in the century and to oversee the reallocation of private and public rights occurring after mid-century. A determination evident not just in matrimony but in all areas of post-Civil War legal practice.

An 1863 Pennsylvania decision illustrates the new legal environment surrounding kin marriages. John Parker married his niece in 1856 but had kept the ceremony a secret. He died in 1861 , a year after a new act prohibiting such marriages, and his wife and mother fought over his estate. The state supreme court followed the advice offered by Bishop and interpreted the statute in light of earlier common law precedents. The justices ruled that since the law contained no express clause declaring such marriages void they would follow

49. Frederick Stimson, American Statute Law (Boston 1910), 666-67; Vernier, American Family Law, I: 173-87. 
the common law practice of treating incest violations as irrelevant after the death of one of the spouses. They defended their ruling as a needed protection for legitimacy and inheritance claims based on functioning marriages. But the judges took it upon themselves publicly to reject an earlier faith that self-policing would control the problem:

We cannot . . refrain from stating that such connections are destructive of good morals and should not only be frowned upon by the community, but very severely punished; and this is unquestionably the view of our criminal code. ${ }^{50}$

In his 1865 Book of Nature, John Aston noted that "it was well known that marriage between near relatives produces unhealthy and imperfect children, but the causes of such a result are not generally understood." ${ }^{11}$ By 1900 such doubts had evaporated and with them a legal tendency to passively tolerate kin violations in defense of contractual rights. Sociologist George Arner thus could confidently predict in 1904: "when rational marriage laws prohibit the marriages of the diseased and the degenerate, the problem of consanguinity will cease to be of vital importance." ${ }_{52}$

\section{Medical Restraints}

Arner's declaration discloses the link forged between nuptial law and the new anxiety over the hereditary effects of matrimony. The reliance on stronger public marriage regulations produced by this alliance altered a final component of the physiological prohibition, the legal assessment of the mental and physical capacity to wed. Restrictions on the nuptial rights of the insane instituted early in the nineteenth century grew more out of an attempt to prevent the victimization of the mentally ill than a desire to inhibit their procreative powers. State legislators and judges used various common law and statutory controls drawn from English cannon law, Parliamentary reforms enacted to protect the insane, common law doctrines, and customary practices to develop a post-revolutionary policy governing the issue.

The law did not make a clear distinction between mental deficiency and insanity. Instead it formally restricted the nuptial rights

50. Parker's Appeal, 44 Pa. St. 309, 312 (1863); and see Harrison v. State, 22 Md. 468 (1863); Walter's Appeal, 70 Pa. St. 392 (1872); Cummings v. State, 36 Tex. Crim. Cts. 256 (1896); Boylan v. Deinzer, 45 N. J. Eq. 485 (1889); McIlvain v. Scheibley, 109 Ky. 455 (1898).

51. The Book of Nature (New York 1865), 50-52.

52. "Consanguineous Marriages in the American Population," Columbia Studies in History, Economy, and Public Law, 31 (1908), 95. 
only of those who at the time of their marriage were clearly unable to lead an independent existence. The prohibition prevented incompetent persons from being compelled to enter a relationship they could not comprehend and stymied those who preyed on the mental difficulties of incompetents to gain access to their property. In applying the law judges eschewed medical definitions of sanity for contractual ones. A subjective judgment of whether the potential spouse could manage the common affairs of life and understand the meaning of matrimony served as the primary gauge of mental fitness for nuptials. In this way insanity too fell under the dominion of the free marriage market. ${ }^{53}$

An 1850 New Hampshire ruling, True v. Ranney, epitomizes the judicial approach. After a twenty-two year old woman had been whisked away and married in Vermont, her parents sued to annul the union. They testified that she could not wash or dress herself, spell or read, use money, tell time, knit or sew, and that-perhaps most telling to a New England jury-she did not know how to properly "get a boiled dinner." Affirming the dissolution of the marriage, Chief Justice John J. Gilchrist declared: "There is every reason to believe that no person so lamentably imbecile as this young woman appears to be, could have the remotest idea of the meaning of a contract for the performance of any of the ordinary duties of life, and still less of a contract of marriage." ${ }_{54}$

The sad plight of the New Hampshire woman illustrates the severe state of incompetence which invoked the curb. Instituted over the dissent of some medical experts, including Isaac Ray, the leading authority on insanity in antebellum America, the legal policy resulted in a very limited use of the restriction. ${ }^{55}$ Equally significant, while most laypersons and professionals believed that mental disabilities had hereditary origins, few acted upon that belief to insist upon harsh restrictions on the nuptial rights of incompetents. Novelist Catherine Sedgwick, whose mother and a brother suffered from mental illness, expressed such sentiments in an attack on Horace Mann. The educational reformer, who as a state legislator had lobbied to create the first Massachusetts lunatic asylum, had advocated more stringent nuptial controls on the insane. Sedgwick responded in 1839 that Mann had not weighed the chance of insanity being repeated in a family against the "certain misery" of inflicting

53. Blackstone, Commentaries, I: 438-39; Browning v. Reane, 2 Phill. 69 (1812); Turner v. Myers, 1 Hag. Con. 414 (1808); Middleborough v. Rochester, 12 Mass. 363 (1815); James Kent, Commentaries on American Law (New York 1826-1829), II: 76.

54. 21 N.H. 53, 54-55.

55. See for example Isaac Ray, A Treatise on the Medical Jurisprudence of Insanity (John Harvard ed., Cambridge Ma. 1962 of 1838 ed.). 
"the heaviest curse that could fall upon ... those whose families have thus been afflicted-of making them as lepers." Even if the disease broke out in branches of a family, the novelist famous for her stories of domestic tragedy confidently asserted, "judicious physical education"' and the observance of "sanitive laws, physical, moral, and intellectual" could "extirpate all disease." 56 A society which resisted biological determinism and which busily constructed asylums with the optimistic faith that even the hereditarily insane could be rehabilitated easily accepted a loose nuptial standard of mental capacity. ${ }^{57}$

In the latter part of the century, growing biological fears tipped the law away from Sedgwick's position and toward Mann's. A continued belief in the hereditary sources of mental illness, the failure of asylums to achieve the cures promised by their founders, along with apprehension about marital life and a new faith in scientific solutions to social ills, all combined to shift the focus of professional and lay interest from rehabilitation to prevention. Language reflected a declining perfectionist faith in individual reformation and the turn to social coercion. During the 1850 s a pejorative new term, feebleminded, came into use as a descriptive label for the mentally ill. ${ }^{58}$ Stringent and well-enforced marriage standards for conjugal fitness became one widely advocated method of intervening in the reproductive process to prevent the birth of feebleminded children. Hereditary alarm became so pervasive that even that arch foe of the active state, Christopher Tiedeman, declared: "If the blood of either of the parties to a marriage is tainted with insanity there is imminent danger of its transmission to the offspring, and through the procreation of imbecile children the welfare of the state is more or less threatened." 59 Much less confident of the wisdom of the free market approach to hereditary than to youthful matrimony, Tiedeman accepted the need for greater public surveillance and reduced contractual rights.

56. Quoted in Normal Dain, Concepts of Insanity in the United States, 1789-1865 (New Brunswick, N. J. 1864), 180. For cases on the subject see Rawdon v. Rawdon, 28 Als. 565 (1856): Cole v. Cole, 5 Sneed 57 (Tenn. 1857); Foster v. Means, Speer's Eq. 569 (S. C. 1844); Keyes v. Keyes, 22 N.H. 553 (1851): Atkinson v. Medford, 46 Me. 510 (1859).

57. David Rothman, The Discovery of the Asylum (Boston 1971); Dain, Concepts of Insanity; Gerald Grob, The State and the Mentally III, A History of Worcester State Hospital in Massachusetts, 1830-1920 (Chapel Hill 1966).

58. Peter Tylor, "Denied the Power to Choose: Sexuality and Mental Defects in American Medical Practice, 1850-1920," Journal of Social History, 10 (1977), 472, 474. For a valuable discussion of these changes see Charles Rosenberg, "'The Bitter Fruit: Heredity, Disease, and Social Thought in Nineteenth Century America," Perspectives in American History 8 (1974), 189-235.

59. Constitutional Limitations, 530. 
Legal procedures, however, offered little assistance to those determined to institute more rigorous tests of mental capacity as a check on nuptial rights. The courts applied legal rather than medical standards and resisted a general definition in favor of case-by-case determinations based on precedents like the Ranney decision. As the Mississippi Supreme Court declared in 1872 after it refused to annul the marriage of William and Mollie Smith because of Mrs. Smith's insanity: "We have not seen a case where the presence of the taint of hereditary insanity ... has of itself been held to be the cause of dissolving the marriage." ${ }^{60}$ Only statutes expressly changing the common law and convincing new arguments in their favor could wean the bench away from its reading of the law.

Reformers and physicians, increasingly self-confident about their professional objectivity, met the challenge posed by the judiciary by devising new attacks and demanding public remedies. Their efforts culminated in the eugenics crusade. Though erected on the scaffolding created by canonical and common law impediments to matrimony, eugenically inspired nuptial laws constituted a major legal departure. They arose from a new assumption that physical deficiencies in themselves abrogated individual nuptial rights because of the State's responsibility to defend itself against unhealthy offspring and pollution of the marriage bed by disease. In $1910 \mathrm{Har}-$ vard political scientist Frederick Stimson pinpointed the essence of the change that made greater public intervention the solution to the problems posed by heredity: "To-day we witness the startling tendency for the State to prescribe whom a person shall not marry, even if it does not prescribe whom they shall. The science of eugenics . . . will place upon the statute books matters which our forefathers left to the Lord." ${ }_{61}$

The eugenics crusade, which reached its height between 1885 and 1920, had a direct and longlasting effect on marriage law. Under its sway eugenically inspired restraints on those afflicted with mental and physical maladies expanded the traditional physiological impediments to matrimony. The additions ensured that for the first time nuptial prohibitions contained explicit medical as well as contractual means of assessing nuptial fitness.

Advocates of biological restrictions touted them as necessary weapons to defend the nation from degeneration. Sociologist Howard complained in a 1901 study that "under pleas of 'romantic love'

60. Smith v. Smith, 47 Miss. 221,219 (1872); Waymore v. Jetmore, 22 Ohio St. 271 (1872); Baker v. Baker, 82 Ind. 146 (1882); St. George v. Biddlefield, 76 Me. 593 (1885); Roether v. Roether, 180 Wis. 24 (1923).

61. American Statute Law, 327; and see Mark S. Haller, Eugenics (New Brunswick, N. J. 1963), 141-43; Donald K. Pickens, Eugenics and the Progressives (Nashville, Tenn. 1968). 
we blandly yield to sexual attraction in choosing our mates, ignoring the welfare of the race." Appealing for a "higher standard of conjugal choice," he contended that experience "shows that in wedlock natural and sexual selection should play a smaller and artifical selection a larger role." Here, he declared, "the state has a function to perform" and then demanded that legislation curtail the nuptial rights of the unfit. ${ }^{62}$

Howard's plea discloses both the goals and the limits of the eugenic marriage law movement. The full program could only be achieved by treating marriage as state controlled mating. The very breadth of such a proposal doomed it to the same legal oblivion reserved for other reforms which required massive increases in state power such as calls for the nationalization of industry. Nevertheless, major alterations did occur. Though the most drastic laws affected only a small segment of the population, they reveal the new reliance late nineteenth century marriage law reform placed on state intervention.

In 1895 Connecticut enacted a statute which fulfilled many eugenic goals. It banned the marriage of feebleminded, imbecilic, and epileptic men and women under forty-five years of age. The law imposed a minimum three year prison sentence on violators. The state supreme court incorporated the act into its supervision of wedlock in 1905 when it approved the dissolution of Marion and Roy Gould's marriage. Marion claimed that her husband had hidden his epilepsy from her. The justices rejected Roy's contentions that the new law unconstitutionally abridged private rights:

Laws of this kind may be regarded as an expression of the conviction of modern society that disease is largely preventible by proper precautions, and that it is not unjust in certain cases to require the observation of these, even at the cost of narrowing what in former days was regarded as the proper domain of individual rights. ${ }^{63}$

The Connecticut action encouraged Kansas (1903), New Jersey and Ohio (1904), and Michigan and Indiana (1905) to impose similar restrictions. By the 1930s forty-one states had enlarged the common law tests of mental capacity with statutes that used terms like lunatic, feebleminded, idiot, and imbecile. The statutes and judicial opinions like the Gould decision indicate a willingness to depart from the

62. Matrimonial Institutions, III: 258; and see Albert Swindlehurst, "Some Phases in the Law of Marriage," Harvard Law Review, 30 (1916-1917), 148.

63. 78 Conn. 242. 
common law defense of contractual rights in the face of major threats to public safety. ${ }^{64}$

Unlike insanity, few precedents existed for using disease to restrict matrimony. But during the final decades of the nineteenth century, apprehension over the transmission of hereditary defects and contagious diseases, especially venereal disease, inflamed the public mind. Reformers bombarded the nation with statistical studies claiming that disease had reached epidemic proportions and with terrifying horror stories of women and children ruined by male sexual deviance and disease. Because the "welfare of the human race is largely bound up in the health and reproductive capacity of the wife and mother,' New York City medical professor Prince A. Morrow pleaded in a 1904 polemic, the "sanitation of the marriage relation becomes the most essential condition of social preservation." A leading member of the hygenic wing of the Social Purity Alliance, he lamented that through "its instrument, the law, the State affords the injured wife the doubtful remedy of separation or divorce, but it does not protect her from this injury." Morrow traced this "callous indifference" to popular acceptance of the inevitability of "evil" and to the cynical assumption that the "communication of disease in marriage" remained a "matter between husband and wife with which the society has nothing to do." Morrow demanded a state ban on diseased grooms. ${ }^{65}$

The persistent efforts of reformers like Morrow and the public revulsion they helped induce convinced more and more lawmakers to enact bans on the marriages of the diseased. In 1899 Michigan legislators passed an act barring those with syphilis or gonorrhea from marrying and imposed a criminal penalty on violators. By the 1930s over twenty-six states and territories had enacted such measures. Generally the statutes were predicated on the concealment of the disease by the afflicted party. Many of them provided for criminal punishment and fines when an individual knowingly wed while infected. ${ }^{66}$

The campaign for medical restrictions in marriage law did not end with the passage of these acts. Reform shifted from deterrence

64. Jessie Spaulding Smith, "Marriage, Sterilization, and Commitment Laws Aimed at Decreasing Mental Deficiency," Journal of Criminal Law and Criminology, 5 (1914), 365-66; Vernier, American Family Laws, I: 190-95.

65. Social Diseases (New York 1904), 20, 331-32; and see John C. Burnham, "The Progressive Era Revolution in American Attitudes Toward Sex," Journal of American History, 59 (1973), 886-908; Pivar, Purity Crusade: George Howard, "Social Control of Domestic Relations," American Journal of Sociology, 10 (1910), 814-15; Thomas Speed Mosby, "Eugenics," Case and Comment, 22 (1914-1915), 22-24.

66. Schouler, Domestic Relations (6th ed.), II: 1350-51; Mary Richmond and Fred S. Hall, Marriage and the State (New York 1929); Vernier, American Family Laws, I: 199-203. 
to prevention. In 1913 Wisconsin became the first state to heed the advice of the most determined reformers when it required prospective grooms to submit to medical tests. Critics complained about the unreliability of the tests and claimed that they violated individual rights. But disease-inspired fears, improved tests, and greater documentation drowned these complaints. Alabama, Louisiana, North Carolina, North Dakota, Oregon, Texas, Virginia, and Wyoming had joined Wisconsin by 1930 . As others followed-and began to include brides-prenuptial medical examinations became a standard procedure. ${ }^{67}$

The new nuptial controls also elicited general judicial approval as valid exercises of the now expanding state police power over matrimony. Many courts did hedge that acceptance by incorporating the acts into traditional common law disabilities and thus again retained a degree of discretion. The bench tended to categorize violations as frauds rather than as criminal transgressions unless expressly compelled to do so by a statute or indictment. The Massachusetts Supreme Judicial Court followed that path in the 1898 case of Smith v. Smith. Emma Smith sued for an annulment. The astonished bride had discovered her husband's syphilitic condition on their wedding night. He denied it, but a doctor confirmed her fears. Traditionally illness could not be considered a nuptial fraud since couples pledged to 'take each other in sickness and health.' But a series of decisions by the same court, beginning with the 1862 ruling of Reynolds $\mathrm{v}$. Reynolds, had held that nuptial violations which went to the 'essence' of the matrimonial agreement qualified as fraud. The court considered Smith's act such a violation. It warned that no woman would be asked to "sacrifice herself to incurable disease and to blight her posterity." 68

The most extreme eugenic measure, sterilization, capped the effort to curtail the nuptial freedom of the unfit. By permanently preventing the mentally, physically, and morally defective from procreating, reformers hoped to allow such unfortunates to rejoin society and enjoy the solace and controls of matrimony without endangering society. Indiana passed the first act in 1907. It authorized the sterilization of confirmed criminals, idiots, imbeciles, and rapists in state institutions upon the approval of a board of

67. Fred S. Hall, Medical Certification for Marriage (New York 1921); Dr. R. W. Schulfeld, "Needed Revisions of the Law of Marriage and Divorce in the United States," Medico-Legal Journal, 15 (1898), 231-39; Tiedeman, Constitutional Limitations, 535; Charles H. Huberick, "Venereal Disease and the Law of Marriage and Divorce," American Law Review, 37 (1903), 226-36; Edward W. Spencer, "Some Phases of Marriage Law," Yale Law Journal, 25 (1915-1916), 58-65; Haller, Eugenics, 141-43.

68. 171 Mass. 404, 407. For a general discussion of marital fraud see Reynolds v. Reynolds, 3 Allen 605 (Mass. 1862); Bishop, New Commentaries, I: 193-236. 
experts. By 1931 twenty-seven states had enacted some form of mandatory sterilization. The acts varied widely in scope; most included the feebleminded and imbecilic. ${ }^{69}$

As the most drastic invasion of nuptial rights, mandatory sterilization generated intense controversy. Courts in Indiana and New York declared statutes unconstitutional deprivations of the right to due process and equal protection of the law. A federal tribunal overturned a Nevada act by terming it cruel and unusual punishment. Repeal or neglect eliminated other statutes or rendered them ineffective. But in 1927 the United States Supreme Court revealed how thoroughly state intervention had permeated marriage law when it approved the sterilization of a thirteen year old Virginia woman. Justice Oliver Wendell Holmes Jr., who had concurred with the 1898 Smith decision while on the Massachusetts bench, asserted: "It is better for all the world, if instead of waiting to execute degenerate offspring for crimes, or to let them starve for their imbecility, society can prevent those who are manifestly unfit from continuing their kind." 70 This vigorous endorsement of the most radical invasion of what had earlier been considered a private right aptly symbolized and summarized the new tenor of physiological restrictions on marriage.

\section{A Progressive Balance}

In 1904 while addressing Congress on the need for uniform legislation on marriage and divorce, President Theodore Roosevelt declared that marriage lay "at the very foundation of our social organization." 71 Roosevelt echoed the sentiments Jesse Root had expressed over a hundred years earlier. But the purpose of the president's declaration reflected the changes that had occurred in the legal means of ensuring that matrimony fulfilled its social responsibilities. Over the course of the nineteenth century nuptial prohibitions and other martial regulations had not been fundamentally renovated but they were selectively redrawn to place matrimony securely in the realm of public as well as private law. The revisions included the reorientation of the physiological restrictions as well as a burst of legislation requiring licenses, registration, formal ceremonies, and other nuptial formalities. The rising belief that family life was too vital to public order to be left beyond the regulatory reach of the

69. Haller, Eugenics, 130-41; Morrow, Social Disease, 366-69; Joseph P. Chamberlain, "Eugenics and the Limitation of Marriage," American Bar Association Journal, 9 (1923), 429; Pickens, Eugenics and the Progressives, 86-101.

70. Buck v. Bell, 274 U.S. 200; and see Haller, Eugenics, 140-41.

71. Quoted in United States Bureau of the Census, Report on Marriage and Divorce (Washington 1909), I: 4. 
state encouraged these new nuptial controls. They created a new balance between public and private rights which remained largely in place until the mid-twentieth century.

The alterations in marriage law indicate that once the traditional ideal of family government had withered away only the state had the authority and legitimacy to take its place as the regulator of nuptials. Nevertheless, turning to the state was a difficult proposition for a society that cherished limited government and personal choice in matrimony as in all other activities. As a result, confusion and uncertainty reigned over just how to govern courtship and marriage. Reformers intent on expanding state nuptial authority often clashed with judges, legislators, and others determined to blunt state intervention into what had been considered private calculation and to protect the public and private spheres of social and economic life carved out early in the century. Because of these conflicts the effort to enlarge the scope of nuptial law achieved uneven results. But in every category the state ceased to be a silent partner. The growing presence of the state in matrimony suggests a gradual rejection of an earlier faith that individual self-interest and voluntary reform could protect the common good. A new reliance on the state to define and protect the public interest replaced that older conviction.

The resort to state intervention in nuptials illustrates how common that impulse became. Changes in marriage law belie the standard historical focus on state intervention as primarily an economic act. On the contrary, the use of public power to promote or impose social and cultural values rivaled in intensity and popularity the more commented upon struggles over state regulation of commerce in the latter part of the nineteenth century. ${ }^{72}$ Though the widespread nature of state activism has been hinted at, it has rarely been addressed by legal historians. The most obvious examples, changes in the law of race, crime, and education or the creation of state welfare bureaus and institutions, have largely been treated as laying in historigraphical ghettos too dark to shed much light on general legal development. But the impulse was much too broad for such casual dismissals. The widespread reliance on state authority must be recognized and its sources identified and explained in order to fully understand the nineteenth century legal system.

Marriage law illustrates how fruitful such investigations may be. It remained a distinctive category of American law over the course of the century because it maintained a dynamic relationship to

72. For similar developments in other areas of family law see Linda Gordon, Women's Body, Women's Right, A Social History of Birth Control In America (New York 1974); James C. Mohr, Abortion in America (New York 1978): and for a brilliant analysis of a similar trend in France see Jacques Donzelot, The Policing of Families, trans. Robert Hurley (New York 1979). 
changes in family life and in sentiments toward the home as well as to evolving attitudes about state intervention. The difficulty of locating a stable consensual foundation for nuptial governance offers a set of telling examples of the struggle to revise an initial postrevolutionary commitment to limited government and individual choice. Yet the legal system succeeded in this case, as in so many others, in creating a remarkably resilient code, one that required some acknowledgment and accommodation from all brides and grooms. 